\title{
First record of Sebekia oxycephala (Pentastomida: Sebekidae) infecting Helicops infrataeniatus (Reptilia: Colubridae), São Paulo State, Brazil
}

\author{
Silva, LAF. ${ }^{a *}$, Morais, $D H .^{a}$, Aguiar, A. $^{a}$, Almeida, WO. ${ }^{b}$ and Silva, RJ. ${ }^{a}$ \\ aDepartamento de Parasitologia, Instituto de Biociências, Universidade Estadual Paulista "Júlio de \\ Mesquita Filho" - UNESP, Campus de Botucatu, Botucatu, SP, Brazil \\ ${ }^{\text {b}}$ Departamento de Química Biológica, Universidade Regional do Cariri - URCA, Campus do Pimenta, \\ CEP 63105-000, Crato, CE, Brazil \\ *e-mail: lidianefissi@gmail.com
}

Received: December 10, 2013 - Accepted: January 31, 2014 - Distributed: May 31, 2015

(With 1 figure)

\begin{abstract}
The genus Helicops comprises 15 species that are widely distributed throughout South America and such species are well adapted to aquatic environments (Ávila et al., 2006). These snakes are active during daytime, feed on fishes and amphibians, and forage in every layer of the water column and surface (Aguiar and Di-Bernardo, 2004).

Pentastomida is a group of parasites with a complex morphology showing "five mouths". Even though Pentastomida is in the Crustacea group, they also present characteristics of onychoforans (Abele et al., 1989). Pentastomida species are parasites of the respiratory tract of vertebrates, and most of the records and new species are associated with reptiles (Almeida and Christoffersen, 2002). In Brazil, five pentastomid species associated with snakes have already been recorded: Cephalobaena tetrapoda Heymons, 1922 associated with Crotalus durissus terrificus Laurenti, 1768 and Liophis lineatus Linnaeus, 1758; Raillitiella furcocerca Diesing, 1863 associated with Boa constrictor Linnaeus, 1758, Coluber lichtensteinii Wiedneuwied, 1824, Drymarchon corais Stejneger 1899, Crotalus durissus terrificus, Xenodon merremii Wagler, 1824 and Lachesis sp.; Kiricephalus coarctatus Sambon, 1910 associated with Dryadophis bifossatus Raddi, 1820, Aporophislineatus Boulenger, 1894, Herpetodryas carinatus Linnaeus, 1758 and Coluber corais Boulenger, 1894; Porocephalus crotali Humboldt, 1808 associated with Crotalusdurissus terrificus; and Sebekia oxycephala Diesing, 1835 (Almeida et al., 2007) associated with Micrurus surinamensis Cuvier, 1817 (Ávila et al., 2013).

Sebekia is a pentastomids genus generally associated with crocodilians, and the species of this genus use fishes as intermediate host. However, the biological cycle of Sebekia oxycephala is still not clear regarding lizards and snakes infections (Venard and Bangham, 1941; Riley, 1986; Junker and Boomker, 2006).

Studies in Brazil have shown that $S$. oxycephala seems to be a generalist species with a behavior similar to other pentastomids already studied (Rego and Eiras, 1989; Almeida et al., 2010). Sebekia oxycephala presents geographical distribution from the southern United States
\end{abstract}

to the southern South America. In Brazil, pentastomid nymphs were reported parasitizing the fishes Serrasalmus nattereri Günther, 1864, Pseudoplatystoma corruscans Spix \& Agassiz, 1829, Phalloceros harpagos Lucinda, 2008 (Almeida et al., 2010) and Serrasalmus marginatus Valenciennes, 1837 (Vicentin et al., 2011), and also the snakes Helicops leopardinus (Schlegel, 1837) (Rego and Vicente, 1988), Nerodia spp. (Overstreet et al., 1985) and Micrurus surinamensis (Ávila et al., 2013).

In July 2012 and February 2013, two snakes Helicops infrataeniatus (Jan, 1865) were sampled in a Conservation Unit (Private Reserve of the Natural Patrimony 'Aguapeí River Mouth') in Castilho municipality, São Paulo State, Brazilian southeast. The snakes were necropsied, however only one was infected with parasites. Three immature pentastomids were found, one in the body cavity and two in the lungs. The parasites were collected, fixed with alcohol $70^{\circ}$ and examined as permanent slides with Hoyer. The pentastomid identification was based on the dimensions of the hooks, copulatoryspiculae of the males (measured with the aid of a microscope fitted with a micrometer eyepiece), number of body rings and oral cavity (Venard and Bangham, 1941; Self and Rego, 1985). The morphological analyses of the pentastomids enabled to identify the species as Sebekia oxycephala (Figure 1). Voucher parasite specimens were deposited at the Coleção Helmintológica do Instituto de Biociências, São Paulo State University, Botucatu, São Paulo State, Brazil, under the numbers CHIBB 7175 and 7176.

The infection of $H$. infrataeniatus with $S$. oxycephala may be related to the semi-aquatic habit and piscivorous diet of this host, since nymphs directly infect the aquatic intermediate hosts, like fishes (Junker et al., 1998; Ávila et al., 2006; Morais et al., 2011). Such affirmation was previously confirmed by Goldberg and Bursey (2004) that found Sebekia sp. infecting Micrurusalleni Schmidt, 1936, which shows terrestrial habit but piscivorous diet. Rego and Vicente (1988) also recorded this parasite associated with the congeneric species $H$. leopardinus from Mato Grosso State, Brazil. 


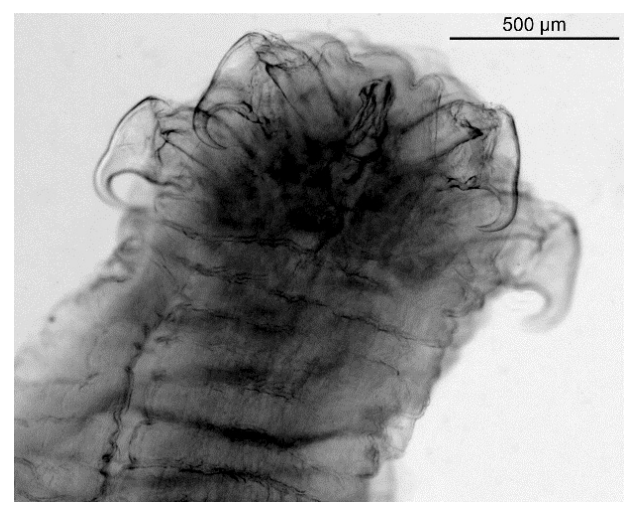

Figure 1. Anterior end of Sebekia oxycephala collected in the body cavity of Helicops infrataeniatus from the municipality of Castilho, São Paulo State, Brazil.

These findings corroborate the fact that $S$. oxycephala shows low specificity for intermediate hosts. This study reports for the first time $S$. oxycephala infecting $H$. infrataeniatus, adding this snake species to the host list of this pentastomid in Brazil and also recording São Paulo State as a new locality for geographic distribution.

\section{Acknowledgements}

The authors are grateful to the Conselho Nacional de Desenvolvimento Científico e Tecnológico (CNPq productivity fellowship process $311713 / 2012-2$ ), the Fundação de Amparo à Pesquisa do São Paulo (FAPESP - process 2011/20186-6) and the Companhia Energética do Estado de São Paulo (CESP).

\section{References}

ABELE, LG., KIM, W. and FELGENHAUER, BE.,1989. Molecular evidence for inclusion of the phylum Pentastomida in the Crustacea. Molecular Biology and Evolution, vol. 6, p. 685-691.

AGUIAR, LFS. and DI-BERNARDO, M., 2004. Diet and feeding behavior of Helicops infrataeniatus (Serpentes: Colubridae: Xenodontinae) in southern Brazil. Studies on Neotropical Fauna and Environment, vol. 39, no. 1, p. 7-14. http://dx.doi.org/10.10 $80 / 01650520412331270927$.

ALMEIDA, WO.,SILVA-SOUZA, AT. and SALES, DL., 2010. Parasitism of Phalloceros harpagos (Cyprinodontiformes: Poeciliidae) by Sebekia oxycephala (Pentastomida: Sebekidae) in the headwaters of the Cambé River, Paraná State, Brazil. Brazilian Journal of Biology $=$ Revista Brasileira de Biologia, vol. 70, no. 2, p. 457-458. http://dx.doi.org/10.1590/S151969842010005000004. PMid:20552150

ALMEIDA, WO.,VASCONCELLOS, A., LOPES, SG. and FREIRE, EMX., 2007. Prevalence and intensity of pentastomid infection in two species of snakes from northeastern Brazil. Brazilian Journal of Biology $=$ RevistaBrasileira de Biologia, vol. 67 , no. 4, p. 759-763. http://dx.doi.org/10.1590/S151969842007000400025. PMid:18278332

ALMEIDA, WO. and CHRISTOFFERSEN, ML. 2002. Pentastomida. In: MORRONE, J. and LLORENTE-BOUSQUETS, J. (Eds.). Biodiversidad, taxonomía y biogeografia de artrópodos de
México: hacia uma sintesis de su conocimiento. Vol. 3. México: Universidad Nacional Autónoma de México. p. 187-202.

ÁVILA, RW.,FERREIRA, VL. and ARRUDA, JAO., 2006. Natural history of the South American water snake Helicops leopardinus (Serpentes: Colubridae) in the Pantanal, Brazil. Journal of Herpetology, vol. 40, no. 2, p. 274-279. http://dx.doi. org/10.1670/113-05N.1

ÁVILA, RW.,MORAIS, DH., ANJOS, LA., ALMEIDA, WO. and SILVA, RJ., 2013. Endoparasites infecting the semiaquatic coral snake Micrurussurinamensis (Squamata: Elapidae) in the southern Amazonian region, Mato Grosso state, Brazil. Brazilian Journal of Biology $=$ RevistaBrasileira de Biologia, vol. 73, no. 3, p. 645-647. http://dx.doi.org/10.1590/S1519-69842013000300024. PMid:24212707

GOLDBERG, SR. and BURSEY, CR., 2004. Coelomic metazoan endoparasites of 15 colubrid and two elapid snake species from Costa Rica. Caribbean Journal of Science, vol. 40, no. 1, p. 62-69.

JUNKER, K. and BOOMKER, J., 2006. Check-list of the pentastomid parasites crocodilians and freshwater chelonians. The Onderstepoort Journal of Veterinary Research, vol. 73, no. 1, p. 27-36. http://dx.doi.org/10.4102/ojvr.v73i1.167. PMid:16715876

JUNKER, K., BOOMKER, J. and BOOYSE, DG.,1998. Experimental studies on the life-cycle of Sebekia wedli (Pentastomida: Sebekidae). The Onderstepoort Journal of Veterinary Research, vol. 65, no. 4, p. 233-237. PMid:10192834.

MORAIS, DH.,AVILA, RW., KAWASHITA, RA.and CARVALHO, MA., 2011. Squamata, Elapidae, Micrurus surinamensis (Cuvier, 1817): new records and distribution map in the state of Mato Grosso, Brazil, with notes on diet and activity period. Check List $=$ Journal of Species Lists and Distribution, vol. 07, no. 03 , p. $350-351$

OVERSTREET, RM., SELF, JT. and VLIET, KA.,1985. The pentastomid Sebekia mississippiensis sp. n. in the American alligator and other hosts. Proceedings of the Helminthological Society of Washington, vol. 52, no. 2, p. 266-277.

REGO, AA.and EIRAS, J., 1989. Identificação das larvas de Sebekia e Leiperia (Pentastomida). Histopatologia em peixes de rios. Brazilian Journal of Biology $=$ RevistaBrasileira de Biologia, vol. 49, no. 2, p. 591-595.

REGO, AA.and VICENTE, JJ., 1988. Excursão científica à Zona do Pantanal, Estado de Mato Grosso, para coletas de helmintos. Ciencia e Cultura, vol. 40, p. 65-68.

RILEY, J., 1986. The biology of pentastomids. Advances in Parasitology, vol. 25, p. 45-128. http://dx.doi.org/10.1016/ S0065-308X(08)60342-5. PMid:3535437

SELF, JT. and REGO, AA., 1985. Reassessments and revisions of certain genera and species of the family Sebekidae (Pentastomida) including description of Sebekia microhamus n. sp. Systematic Parasitology, vol. 7, no. 1, p. 33-41. http://dx.doi.org/10.1007/ BF00010159.

VENARD, CE., and BANGHAM, RV., 1941. Sebekia oxycephala (Pentastomida) from Florida Fishes and Some Notes on the Morphology of the Larvae. The Ohio Journal of Science, vol. 41, p. $23-28$.

VICENTIN, W., VIEIRA, KRI.,COSTA, FES., TAKEMOTO, RM., TAVARES, LER. and PAIVA, F., 2011. Metazoan endoparasites of Serrasalmus marginatus (Characiformes: Serrasalminae) in the Negro River, Pantanal, Brazil. Revista Brasileira de Parasitologia Veterinária, vol. 20, no. 1, p. 61-63. http://dx.doi.org/10.1590/ S1984-29612011000100012. PMid:21439234 